\title{
Local Wisdom Values in the Pujawali Tradition
}

\author{
Joni Pranata ${ }^{1}$, Hadion Wijoyo ${ }^{2}$, Agung Suharyanto ${ }^{3}$ \\ ${ }^{1}$ Elementary School 5 Pemenang, Indonesia \\ ${ }^{2}$ STMIK Dharmapala Riau, Indonesia \\ ${ }^{3}$ Public Administration Study Program, Faculty of Social and Political Sciences, Universitas Medan Area, Indonesia \\ dhammosubho@gmail.com, Hadion.wijoyo@lecturer.stmikdharmapalariau.ac.id,agungsuharyanto@staff.uma.ac.id
}

\begin{abstract}
This study aims to determine the local wisdom of the Buddhist community in Lombok, especially North Lombok in relation to the environment, nature, and plural social relations. The research method was carried out qualitatively on Buddhist communities in North Lombok Regency. This research results in the finding that basically the local wisdom of the Buddhist community is extracted from the experience of the community from the acculturation of the Majapahit Kingdom tradition which is very familiar with its environment and has long lived in a community culture that is one with nature, known asPujawali / memareq / worship. The local wisdom of Pujawali custom is a social and cultural condition which contains cultural values that respect and are adaptive to the natural surroundings, and are arranged steadily in a society's customs. Even though they are often considered old-fashioned, the values they teach and the practices they carry out are still a regular way of maintaining the environment and good relations between and within religious communities because they still hold strong beliefs about protecting nature means protecting life. Mujawali's wisdom teaches about maintaining harmony and unity, things that cannot be negotiated because actually the people of North Lombok have one ancestor in line with that in North Lombok the people hold the principle of helping merenten (we are all brothers).
\end{abstract}

Keywords local wisdom values, pujawali tradition

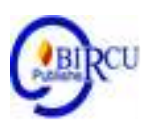

\section{Introduction}

Cultural traditions develop in the Indonesian region which is rich in works from Cipta, Karsa that brings people to the values in it. The value of living together as social beings, needing others with mutual help which is manifested in mutual cooperation and togetherness has begun to erode. People began to be preoccupied with their own affairs, had started to become individualist. Togetherness began to fade and mutual cooperation as the glue and a place for friendship began to be forgotten and replaced with nominal (money).

The nature of indifference or individualism makes the order in society more stretched and some even do not know each other with their neighbors. This shows that values as social beings are starting to fade. If we are Looking back to antiquity, togetherness was echoed, mutual cooperation is a link in the community to ease each other's burdens within the frame of a sense of kinship.

Koentjaraningrat in Martozet (2019) states that "Culture is the whole idea and work of humans, which must be familiarized with the learning process, along with the whole of the 
results of the mind and his work". In essence the culture itself consists of several elements including; language, people belonging to a group, religion, beliefs, and religious system

Cultural customs as a unifier in society, provide space for gathering, sitting equally without differentiating one another and being able to respect each other. There are many cultural customs that have developed in Indonesia, each region has its own cultural customs as well as the role and noble values contained therein. Ethics, manners, have been taught from generation to generation by predecessors (Ancestors) and continue to this day. The respect given to the Ancestors through the pujawali tradition that exists in Lombok Buddhist society in particular still survives today.

Williams in The Long Revolution (1961) shows three general categories in the definition of culture. There is, first, the 'ideal', in which culture is a state or process of human perfection, in terms of certain absolute or universal values. The analysis of culture, for this definition, is essentially the discovery and description, in lives and works, of those values which can be seen to compose a timeless order, or to have permanent reference to the universal human condition. Then, second, there is the 'documentary', in which culture is the body of intellectual and imaginative work, in which, in a detailed way, human thought and experience are variously recorded. (Soqandi et al, 2020)

Ethnicity as one that sustains a sense of primordialism is often interpreted as a social group in a social or cultural system that has a certain meaning or position because of heredity, customs, religion, language, and so on. Members of an ethnic group have a common history (ancestry), language, value system, customs, and traditions. Overall, the ethnic group takes an important position in the social interaction of the intermingling process in all ethnic groups of indigenous peoples in the social community. However, sensitivity to cultural differences is needed because an approach that is too fast can cause internal conflict for ethnicity itself. In such circumstances, the knowledge and skills of local leaders are needed to improve behavior in sensitive areas is very important. (Angkat et al, 2019)

Pujawali or adore is something that is very attached to the people of Lombok, especially those who adhere to Buddhism. This worship is like timeless from time to time and has become like an obligation in the midst of society to carry out the pujawali tradition, even this worship can be a unifier in the midst of diversity, worship or respect for ancestors through traditional Pujawali rituals / this worship can involve the three religions in North Lombok district and pray with their respective beliefs without any friction.

\section{Research Methods}

The method used in this research is to use a qualitative approach with descriptive analysis method. Qualitative research is an inquiry strategy that emphasizes the search for meaning, understanding, concepts, characteristics, symptoms, symbols, and descriptions of a phenomenon, is focused and multimethods, natural and holistic, prioritizes quality, uses several methods, and is presented in a narrative (Yusuf, 2017).

Sources of data in qualitative research are sources or Buddhist communities, especially by observing in the field. In this study, the data source was taken using purposive sampling method, which is the collection of data from people who are considered to know the most about the issues to be studied. (Bah et al., 2020a; Bah et al., 2020b). The instrument in this research is the statements in the form of a questionnaire that are given directly to the object of research, namely the local community who usually performs the ritual of Pujawali / worship in North Lombok Regency. 


\section{Result and Discussion}

The findings in this study are that through the traditional Pujawali ritual, the community instills the values of morality, ethics and respect for the universe so that they understand the greatness of the Creator. Pujawali makes everyone together in a difference because the traditional pujawali ceremony is also followed by people of other religions as a form of respect for ancestors. Strengthened by the Lontar Piagam inscription made of copper, explaining Gajah Mada's journey on Earth Lombok, which strengthens that there are still siblings despite different beliefs, such as Tebango (Buddhist) and Menggala (Islam) hamlet.

The Pujawali ritual is a means of cultivating the feeling (mind) in order to have a righteous heart, thoughts and actions or to become a unity so that it becomes a human being with good character, filial piety as a form of respect for the motherland who has given everything in human life.

Puja Wali / Worship is a traditional ritual that is shown to honor the ancestors. Respecting ancestors is a very important inculcation of values for generations to be able to be inferior and respectful to others. Respecting ancestors even though they do not exist in the world by making offerings and sharing of services is a form of human attitude in order to be able to remain introspective in order to appreciate what is in front of them.

When they are able to respect their ancestors even though they are not visible (already dead), then this is the essence of respect. By being able to respect our ancestors, we will be more able to respect the people around us, even all creatures and the universe, which are reflected in the symbol of red and white porridge which means to respect and respect the earth and nature (motherland). Respect for origins (wiwitan) will bring humans to the highest contemplation, namely God Himself, because in truth respect for ancestors through the customs of the wali puja is to God Almighty.

Pujawali / memareq / worship this is generally done twice a year known as Muja Nunas Kaye (asking for blessings and safety) and Muja Puleq Kaye (returning the results obtained from the blessings that have been requested such as crops and so on), this is actually a reflection of the public's gratitude after doing activities for a year. Muja wali is a customary and cultural heritage from ancestors that teaches memory of origins (historical values), values of togetherness, mutual cooperation, and spiritual / religious, social and artistic values.

\subsection{Historical Value}

Judging from the history contained in the Charter palm (which was made on Saturday, the month of Sada, the year of Wawu) states Gajah Mada's journey from Java to Bali then to Lombok via the Port of Bali which is now known as Carik Port in Bayan, North Lombok Regency now.

His journey is described from Bayan traveling to all corners of Lombok Island and even to Bima. During the trip, it was mentioned that the governor of Gajah Mada and his entourage built small government offices in the areas visited. This shows that it is in accordance with the slogan in North Lombok which says the people of North Lombok are especially brothers (helping merenten). His walk in building these positions suggests that there is a relationship with one another. This is held firmly by the community even though they have different beliefs but have one ancestor and must protect each other and maintain good relations.

This can be seen very clearly in Tebango Hamlet which is Buddhist with Dusun Mempala which is Muslim has a very close relationship as evidenced by the Lontar Charter which is half owned and will not be complete if the reading is not put together so that when there is a traditional event, the two hamlets are mutual need, this shows that harmony and cooperation have been inherited from ancient times even before the Indonesian state was formed. 


\subsection{Social Value}

Pujawali has an impact on togetherness in doing good together, mutual respect through deliberation, there is a harmonious relationship both with local residents and from various regions because this event is attended and attended by all Buddhists, especially and nonBuddhists. There was interaction, and even increased income with the existence of night markets around the area of worship events such as the Bageq Sari worship that the author witnessed.

\subsection{Spiritual / Religious Value}

Pujawali gives an understanding that in this life we must be able to build a soul (consciousness) within us so that we can appreciate the universe, like the smallest life, synergize with nature so nature will give everything. This makes the Buddhist community especially respect plants as the source of life, not mean to idolize them. Everything in this world should be appreciated because the universe is us and we are part of the universe.

The soul (consciousness) that is awakened or trained, then we build our body / body like a piece of the Indonesia Raya song which states "wake up the soul, wake up the body" this implies that the consciousness / soul is more entitled because without it this body is nothing like a corpse that can only lie stiff. Practicing mindfulness through respect for all beings, instilling the value of caring and being careful / introspective in every Action and based on love, compassion and wisdom.

Wisdom includes a mental state that is not filled with anxieties and worries, doubts, free from feeling tense, with a calm mind purifying one's mind from restlessness and worry and doubt, living as if it has been freed from mental confusion and its mind is in goodness (D.III .49). Condition without anxiety (SV420).

The steady state of mind having a wise perspective enables the mind to perceive phenomena for what they are. This understanding eliminates anxiety and worry so that inner calm can be realized (AI3).

\subsection{The Value of Gotong Royong}

This traditional ritual cannot run without cooperation, one another needs each other because there are so many preparations that must be made from the Gamelan, the traditional institution that leads the ceremony, namely Mangku Ayu (an elder who understands traditional procedures). Mutual cooperation by taking part in the work together, making work feel light, there is a sense of togetherness, belonging to each other and responsibility.

\subsection{Art Value}

Puja ritual cannot be separated from art, because in this ritual using gamelan and dance in the process of the program, gamelan which is the result of the creativity of the community which shows the harmony of each tone and dance that describes the soul (consciousness) that occurs in the gamelan (wasp). The harmony and harmony that complement each other make this art beautiful, as an illustration that differences that have harmony will lead to beauty.

The harmony and movement of the soul that produces dance is a form of the description of the soul (consciousness) and the body (physical) must be in line in order to produce good work. However, if they are not in harmony then this is what creates chaos and destruction. 


\subsection{Meaning of Infrastructure in Rituals}

\section{a. Water}

Water is the source of life, water is used in rituals as blessed water as a symbol of humility. The water in the container will be calm, like a day that is practiced and managed with meditation will have a good level of calm. A calm and controlled heart will lead to a better life, of course this calm will be obtained by training yourself and controlling your senses so you don't go wild.

This blessing water is believed by some people to be able to bring healing and also as a blessing. Strong belief and good deeds done before or when worship takes place will be able to condition for healing, Return to the goodness and belief that is owned.

\section{b. Candle}

The candle is a symbol of light and as a signpost, with its light a person will be able to see the right path, so also a controlled mind will lead to self-salvation. It is myself who makes myself evil, myself tarnished myself, and myself who causes evil to occur. But it is oneself who becomes holy, holy and tarnished depending on oneself not others, no one else makes it holy (Dh.165).

\section{c. Flower}

Flowers are the result of the motherland which is very abundant in this archipelago, used as a means of worship because of its fragrant smell and beautiful shape, but more than that flowers are a symbol that in fact everything is impermanent, will experience decay like a beautiful flower will wither, so our bodies will age, get sick and die.

Understanding this impermanent condition, so that we as humans can contemplate that time cannot be stopped, so that in life we must do good, not be arrogant, stay introspective, so that life is not in vain and when it's time we can die in peace.

\section{d. Fruits}

Fruits or often called offerings are a symbol of virtue, if we are doing good, of course we want good fruit (reward) from our actions.

\section{e. Incense}

Incense gives a fragrance that can go against the wind, this incense symbolizes the goodness of a person who will bring his name to fame everywhere, so that using incense will remind him to do good, avoid evil, and keep a good name.

\section{f. Betel}

Betel leaf is inseparable from traditional rituals because betel is a necessity in the past and is used as a basic thing to entertain guests. This proves that betel is like a basic necessity which is used as an offering to entertain respected ancestors or as a medium of communication for the sharing of services and respect.

\section{g. Langeh}

Langeh made from coconut milk, lageh is used for cleaning before entering the worship area. This is a symbol to enter a sacred area or place of worship that we must clean first. Clean here is not only physically but also we must be clean so that we can perform rituals of honoring our ancestors with our hearts. Because true devotion is an offering from a sincere heart. 
After performing pelangehan, we use white sembeq as a symbol of purity and father (bapak angkoso) who teaches that a man must be able to refute the motherland, meaning here by continuing to train himself to be able to conquer lust so that it becomes pure or clean.

\section{h. Sembeq}

Sembeqmade of red siri, this sembek is usually given after the ritual and placed on the forehead. This red Sembeq symbolizes the motherland, thus teaching mankind to appreciate the earth on which it stands.

\subsection{Puja Guardians as Adhesives}

This pujawali / worship / memarek ritual is led by a mangku and has its own procedures, however, in this traditional ceremony, it does not forget the beliefs held by the community, there is even prayer together according to their respective beliefs. This shows that from time immemorial, unity and togetherness have been implemented by our ancestors.

Beliefs can be different but do not become hostile and divisive. The teachings of the importance of togetherness and unity were demonstrated by our ancestors through the wali puja which has been passed down to this day.

\section{Conclusion}

Pujawali is a custom and culture that is able to unite diversity because it is true that customs and culture are able to bond human beings in the archipelago (Indonesia), especially those with religious, ethnic and cultural backgrounds with spiritual values. Puja wali is an ancestral relic from an ancient banquet that gives a sign or transmits teachings about devotion and respect for all beings and the universe. Respect for ancestors through wali puja will actually speak out in the highest respect for the perfection of the soul (consciousness) which is capable of giving sincere devotion and every practice is shown to the Supreme Life (God Almighty)

\section{References}

Angkat, M. et al. (2019). Construction of Religious Identity in Pakpak Culture Community in Dairi District. Budapest International Research and Critics Institute-Journal (BIRCIJournal). P. 487-494.

Bah, Y.M., Ridwan, M., Suharyanto, A., \& Amal, B.K., (2020a), Social Work Research, Medan: Bircu Publisher

Bah, Y.M., Ridwan, M., Suharyanto, A., \& Amal, B.K., (2020b), Introduction to The Fundamentals of Social Work, Medan: Bircu Publisher

Dhammapada, (2000), The Word of The Doctrines. Terjemahan Norman. (2000). Oxford: Pãli Text Society

Dharma, B. ., Wijoyo, H. ., \& Anjayani, N. S. . (2020). Pengaruh Pendidikan Sekolah Minggu Buddha terhadap Perkembangan Fisik-Motorik Peserta Didik Kelas Sati di Sariputta Buddhist Studies. Jurnal Ilmu Agama Dan Pendidikan Agama Buddha, 2(2), 71-82. Retrieved from https://journalstabdharmawidya.ac.id/index.php/contents/article/view/16

Fransisca, A., \& Wijoyo, H. (2020). Implementasi Metta Sutta terhadap Metode Pembelajaran di Kelas Virya Sekolah Minggu Sariputta Buddhies. Jurnal Ilmu Agama dan Pendidikan Agama Buddha, 2(1), 1-12. 
Martozet and Nurwani. (2019). Sentimental Values in Tor-Tor Parsiarabu in Tomok Toba Samosir Village. Budapest International Research and Critics Institute-Journal (BIRCIJournal). P. 167-171.

Nikaya, A, (1979), Dialogue of The Buddha, Vol III. Terjemahan David, Rhys. London: The Pali Text Society.

Nikaya, A. (1993), The Book of Gradual Saying, Vol. I Terjemahan Wooward, F.L \& Here, E.M, London: The Pali Text Society.

Nikaya, S., (1980), The Book of Kindred Sayings, Vol V. Terjemahan Woodward, Davids (Ed). London: The Pali Text Society.

Perbowosari, H., Hadion Wijoyo, S. E., SH, S., MH, M., \& Setyaningsih, S. A. (2020). Pengantar Psikologi Pendidikan. Penerbit Qiara Media.

Pranata, J., \& Wijoyo, H. (2020). Analisis Upaya Mengembangkan Kurikulum Sekolah Minggu Buddha (SMB) Taman Lumbini Tebango Lombok Utara. In Prosiding Seminar Nasional Pendidikan (Vol. 2, pp. 778-786).

Pranata, J., \& Wijoyo, H. (2020). Meditasi Cinta Kasih untuk Mengembangkan Kepedulian dan Percaya Diri. Jurnal Maitreyawira, 1(2), 8-14.

Soqandi, M. et al. (2020). Cultural Materialism in Lorca's Poetry. Budapest International Research and Critics Institute-Journal (BIRCI-Journal). P. 682-691

Suci, I.G.S., Suyanta, I.W., Darna, I.W., Wijoyo, H., \& Setyawati, E (2020) A Measure Of Effectiveness Level Of Online Learning Amid Covid-19 Pandemic In The Course Of The Project Management Information Systems (Case Study In STIKOM Yos Sudarso Purwokerto). Journal of Critical Reviews, 7 (12), 4059- 4069. doi:10.31838/jcr.07.12.586

Wijoyo, H. Peranan Lohicca Sutta Dalam Peningkatan Pendidikan Karakter Dosen Di STMIK Dharmapala Riau. JGK (Jurnal Guru Kita), 3(4), 315-322.

William, H., \& Wijoyo, H., (2020). Manfaat Etika dalam Berwirausaha menurut Pandangan Buddhis. Jurnal Ilmu Agama Dan Pendidikan Agama Buddha, 1(1), 45-54. Retrieved from https://journal-stabdharmawidya.ac.id/index.php/contents/article/view/13

Yahya, M., \& Wijoyo, H. (2020). Developing School Information Program: Integrated Management System based on Character Value at SMP Negeri 9 Tapung. International Journal of Asian Education, 1(3), 179-186.

Yusuf, M. (2017). Metode Penelitian: Kuantitatif, Kualitatif, dan Penelitian Gabungan. Jakarta: Kencana. 